\title{
The diversity of endophytic fungi associated with Piper nigrum in the tropical areas: A recent study from Kutai Kartanegara, Indonesia
}

\author{
SOPIALENA ${ }^{1, \vartheta}$, SUYADI $^{1}$, MUHAMAD SAHIL ${ }^{1}$, JULI NURDIANA ${ }^{2, \vee \vartheta}$ \\ ${ }^{1}$ Program of Plant Pests and Disease Science, Faculty of Agriculture, Universitas Mulawarman. Jl. Pasir Belengkong, Kampus Gunung Kelua, Samarinda \\ 75119, East Kalimantan, Indonesia. Tel.: +62-541-749161, Fax.: +62-541-738341. "email: sopialena88@gmail.com \\ ${ }^{2}$ Program of Environmental Study, Faculty of Engineering, Universitas Mulawarman. Jl. Sambaliung No. 9, Kampus Gunung Kelua, Samarinda 75117, \\ East Kalimantan, Indonesia. Tel.: +62-541-749315, Fax.: +62-541-736834.”email: julinurdiana@gmail.com
}

Manuscript received: 1 July 2018. Revision accepted: 18 October 2018.

\begin{abstract}
Sopialena, Suyadi, Sahil M, Nurdiana J. 2018. The diversity of endophytic fungi associated with Piper nigrum in the tropical areas: a recent study from Kutai Kartanegara, Indonesia. Biodiversitas 19: 2028-2034. This research aimed to identify the diversity of endophytes fungal in the root and leaves of Piper nigrum Linn. This research contributes to the knowledge gaps by focusing the discussion on the Endophytic fungal communities of Piper nigrum Linn in tropical areas at Kutai Kartanegara, Indonesia. Two certain plots within the study area were selected based on the different characteristics of topographic contours. The locations, named Plot A was characterized by ramps area, while plot B was sloping or hilly area. A total of 55 isolates were obtained from the root and the leaves of healthy plants, 35 isolates were from Plot A and the other 20 isolates were from plot B. Based on Shannon index (H'), both of the plots corresponded to the same genus; namely Aspergillus sp., Fusarium sp., Nigrospora sp., and Trichoderma sp, and categorized as medium diversity. In this regards, this study confirms that the genus Aspergillus sp. and Fusarium sp. represent a large part of the diversity of Endophytes fungi. As the study indicates that plot B has higher diversity of endophytic fungi compared to plot A, it shows that the hilly area turns out to be a better location for Piper nigrum Linn.
\end{abstract}

Keywords. Pepper, Endophytic fungi, diversity index, dominance index.

\section{INTRODUCTION}

Pepper (Piper nigrum L) is a type of plant which is widely used as a spice and pepper oil. In Indonesia, pepper becomes the fifth largest foreign exchange earner in the spice group and the fifth after rubber, tea, oil palm, and coffee. Indonesia is one of the world's second largest exporter of pepper. The largest pepper producing provinces in Indonesia included Lampung, Bangka Belitung, South Sumatera and East Kalimantan (Directorate General of Plantations GOI 2011).

In the cultivating process; either modern or conventional, many plant-disturbing organisms such as pests or diseases get in the way and cause cropping disturbances. The diseases may be caused by viruses, bacteria or fungi, which are pathogenic to pepper plants and could result inthe reduced crop production. Nevertheless, some fungi have mutualism interaction properties to the host called endophytic fungi. Endophytic fungi are known to live in plant tissues such as leaves, flowers, fruits or plant roots over a period and can live by forming colonies in plant tissues without harming the host (Clay 1988). According to Azevedo et al. (2000) and Khastini et al. (2014), endophytic fungi have an important role in host tissue which exhibits a mutualistic interaction, i.e., positive interaction with the host and negative interaction with plant pest organisms.

Endophytic fungi can produce secondary metabolites from their host plants by adopting some genetic information from its host (Strobel and Daisy 2003; Rubini et al 2005). Meanwhile, Worcher et al (2013) stated that endophytic fungi would benefit from the supply of nutrients, and can endure the unfavorable environmental pressures. On the other hand, host plants can benefit from the induction of resistance to various pressures, both by biotic and abiotic factors, and can also increase their growth, through the production of phytohormones, increased access to minerals and nutrients, and synthesis of antagonistic metabolites (Labeda 1990; Tejesvi et al. 2010; Drigo et al. 2010).

Associated endophytic fungi in host plants may vary (Azevedo et al. 2000; Rodriguez 2009; Saunders et al. 2010; Suyadi et al. 2017). In tomato plants, for instance, there are several genera of endophytic fungi such as Acremonium sp., Aspergillus sp., Cephalosporium sp., Fusarium sp., Helicocephalum sp., Penicillium sp., and Rhizopus sp. (Wulandari et al. 2014). Whereas fungi found in leaf tissues, stems and roots of potato plants consisted of 12 genera (Tirtana et al. 2013). Further, Puspita et al. (2013) found that endophytic fungi within the genus Colletotrichum was dominant in citrus plants. More number of endophytic fungi were isolated from plant parts of clove, i.e., Curvularia sp., Colletotrichum sp., Mucor sp., Gonatobotryum sp., Aspergillus sp., Beltrania sp., and Aspergillus sp. (Shofiana et al. 2015). Moreover, Mandyam et al. (2013) and Wang et al. (2014) also mentioned that the presence of endophytic species always associated with the host' microhabitat conditions and genotype of the host plants and the endophytic fungi. Thus it affects the 
diversity of endophytic colonies and host infectivity (Borer et al. 2013; Aaron et al. 2016).

Considering the abundant studies related to endophytic fungi, however, the analysis of endophytic fungi in pepper plants is limited, particularly in Indonesia. On the other hand, pepper plants have an important role in Indonesian economy. Therefore, this study considers that it is very important to analyze the diversity of endophytic fungi in the pepper plant to increase its productivity. As a result, this study can improve the yield of pepper plant in the areas with poor endophytic association by investing the potential mushrooms to become endophytic fungi.

\section{MATERIALS AND METHODS}

\section{The leaf and root sampling}

This study was conducted in Batuah Village, Loa Janan, Kutai Kartanegara District, East Kalimantan, Indonesia from March to May 2018. The data collection of endophytic fungi on leaves and roots of pepper plant was conducted by using a systematic method (systematic sampling). The sample of plants were located at the position of the diagonal line (Figure 1); five plant samples were taken from the healthy plants exhibiting no symptoms of pests and diseases attack (Figure 2. A-B). From each of the selected sample (Figure 2.C-F), a stratified random sampling was applied to identify and divide the leaf and root into strata. For the root, three strata were taken into consideration; at a depth of 2, 4 and $6 \mathrm{~cm}$ (Figure 3. A-C).

\section{The isolation of endophytic fungus}

Endophytic fungi were isolated by the following steps: the surface of leaves and root samples were sterilized using the alcohol and aquadest to make the growing fungus appear within the leaf tissue and roots of the pepper plant. Each of the sample was cut at $\pm 1 \mathrm{~cm}$ in length, and was sterilized using 5\% NaOCL solution. The samples were later soaked in $70 \%$ alcohol in approximated one minute. This process was replicated twice, before drying it using the sterile tissue and growing it into the Potato Dextrose Agar (PDA) media inside the petri dish. In the last rinse, about $1 \mathrm{ml}$ of aquadest were poured into new PDA media and used as a control. If fungus grew in the controlled sample, then the isolated fungus from the leaf and root samples are not endophytic fungi, as the endophytic fungi only found in healthy plants to help them increasing the resistance of the plants and absorbing the nutrients. On the other hand, the fungus found in the sick plants, are classified as pathogen that harms the plants instead of the biological agents.

\section{Purification}

Any fungal colony that grew later was purified on a new PDA medium. Purification was done on every fungal colony that was considered distinct based on macroscopic morphology that includes the color and shape of the colony. Each of these microorganisms was separated, taken using an ose needle, and then grown again in a petri dish containing a solid PDA. If the fungus that grows is still mixed with other mushrooms, there is a need to perform another purification to obtain the purely isolated fungi.

\section{Preparation}

Fungi that have been successfully purified on PDA media, were later incubated for 7-10 days in the wet tissue covered by a glass cover.

\section{Observation and identification}

This study employed a direct survey and observation to collect the data in the field. The information collected was used to identify the diversities of endophytic fungi in two different areas. The areas were selected based on the different topography and the pepper cultivation methods at two different locations in Batuah Village. The collected microorganisms were identified based on Barnett and Hunter (1988) by matching some of the morphological characters; macroscopically and microscopically.

\section{Data analysis}

Diversity Index $\left(H^{\prime}\right)$ of Shannon (Odum 1971; Goswami 2015)

The H' diversity index was used to determine the diversity levels of root and endophytic leaf fungi in two locations in Batuah Village. The formula for calculation of diversity index is as follows:

$$
\mathbf{H}^{\prime}=-\sum \mathbf{P i} \ln (\mathbf{P i}) ; \mathrm{Pi}=\frac{n i}{N}
$$

Where,

$\mathrm{H}^{\prime}$ : Shannon-Wienner diversity index

ni : Number of individuals of type I

$\mathrm{N}$ : Number of individuals of all types

The diversity level was determined based on the criteria according to Brower and Zar (1977) and defined as follows:

$$
\begin{array}{ll}
\mathrm{H}^{\prime}<1 & : \text { low diversity } \\
1<\mathrm{H}^{\prime}<3 & : \text { medium diversity } \\
\mathrm{H}^{\prime}>3 & : \text { high diversity }
\end{array}
$$

\section{Uniformity Index (E) (Ludwig and Reynold, 1988)}

The uniformity index is used to determine the balance of the fungal community. It is based on the size of the similarity of the number of individuals among species within a community. The formula for calculation of uniformity is as follows:

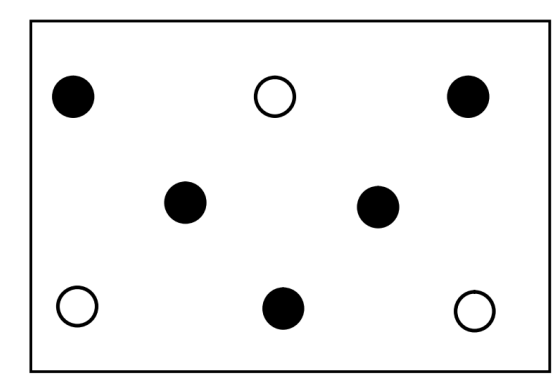

Figure 1. An illustration of the sampling plots. : Plant samples 


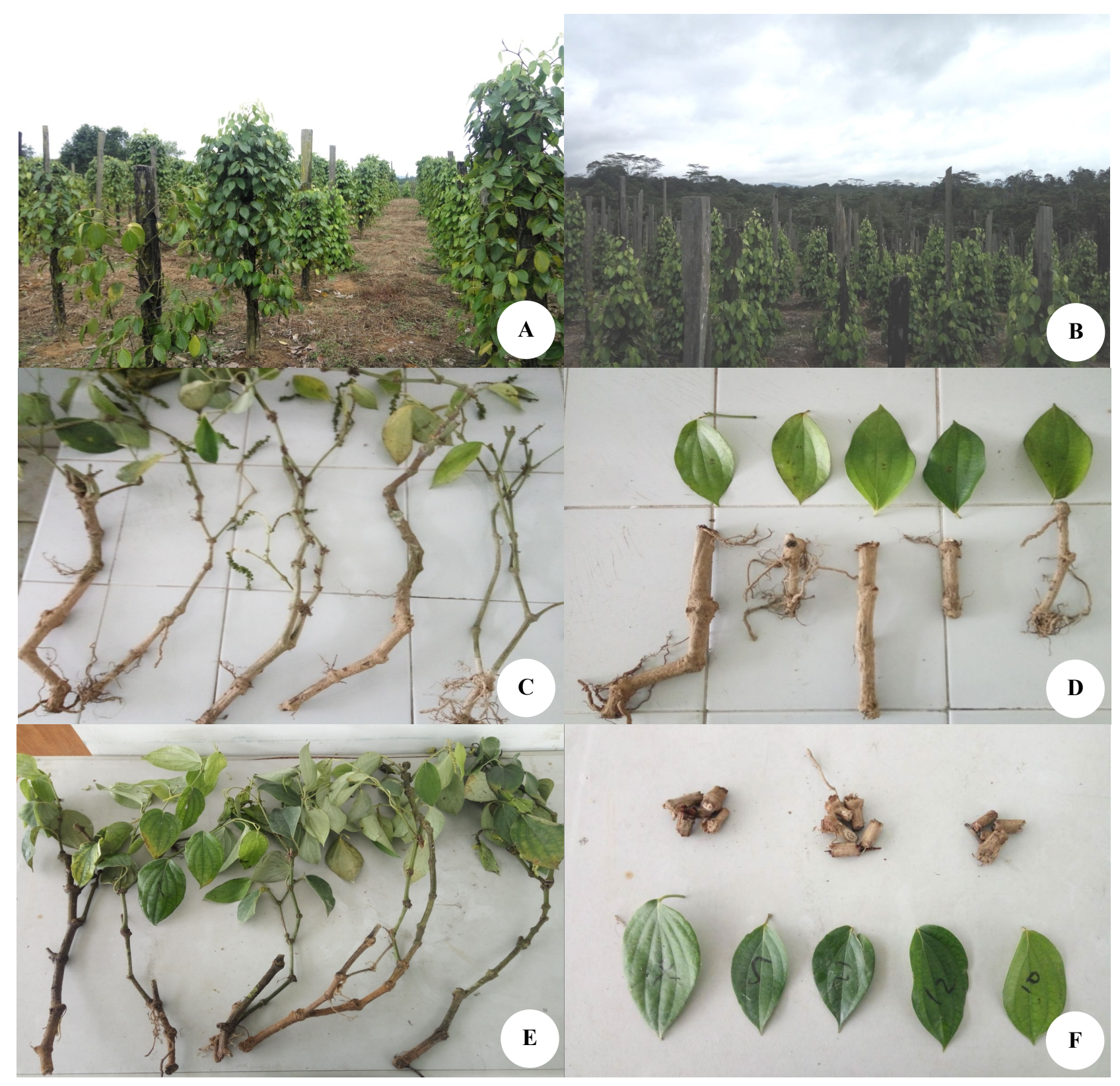

Figure 2. A. Sampling location in Plot A, B. Sampling location in Plot B, C. The pepper plants selected as samples in Plot A, D. The leaf and root samples in Plot A, E. The pepper plants of Plot B, F. The leaf and root samples in Plot B

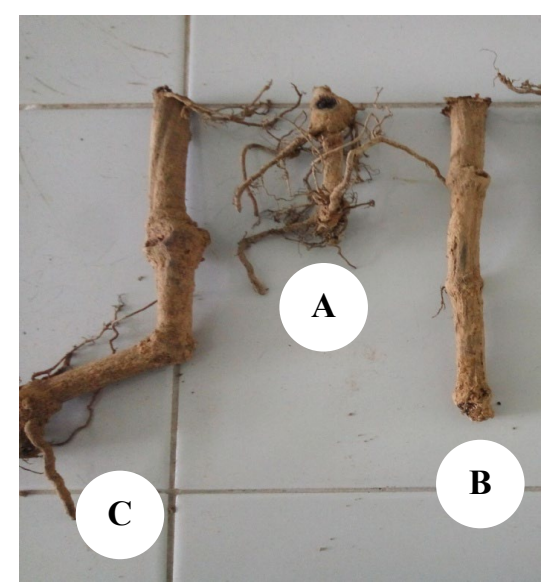

Figure 3. Three root strata A. $2 \mathrm{~cm}$, B. $4 \mathrm{~cm}$, C. $6 \mathrm{~cm}$

$$
E=\frac{H^{\prime}}{\ln s}
$$

Where,

E : Uniformity index

$\mathrm{H}^{\prime}$ : Shannon diversity index

s $\quad$ : Number of genus/species $\square$

The uniformity level was determined based on criteria according to Brower and Zar (1977) and defined as follows:

$0.00<\mathrm{E}<0.50 \quad$ : Small uniformity, depressed community

$0.50<\mathrm{E}<0.75$ : Moderate uniformity, community 1

$0.75<\mathrm{E}<1.00$ : High uniformity, stable community 


\section{The dominant index (C) (Odum, 1971)}

The dominant type index is used to determine the dominance of endophytic fungus species in a community. The Dominance index was calculated using the following formula:

$$
\mathrm{C}=\Sigma(\mathrm{ni} / \mathrm{N})^{2}
$$

Where,

C : Simpson dominance index

ni : Number of individual types I

$\mathrm{N}$ : Total number of individuals

The value of dominance index ranged from $0-1$ and based on the criteria proposed by Hamsiah (2006) and Hamsiah et al. (2016) as follows:
$0.00<\mathrm{C}<0.50 \quad$ : Low
$0.50<\mathrm{C}<0.75 \quad:$ Medium
$0.75<\mathrm{C}<1.00 \quad:$ High

\section{RESULTS AND DISCUSSION}

\section{The general condition of the research sites}

The study site was located in Batuah Village, Loa Janan, Kutai Kartanegara District, East Kalimantan, Indonesia. Batuah lies at an altitude of $500 \mathrm{~m}$ above a sea level with monthly rainfall between $66.9-212.7 \mathrm{~mm}$ or about 13-18 rainy days per month. The rainy season begins between April-August. The relative humidity was $87 \%$, and the average air temperature recorded was between $25-27^{\circ} \mathrm{C}$, whereas the temperature difference between maximum and minimum, was about $14^{\circ} \mathrm{C}$. In addition, based on the data collected from the Meteorological, Climatology, and Geophysics Bureau, the average rainfall in the area of Loa Janan and its surrounding was about $155.4 \mathrm{~mm}$ per year.

The location of the study was divided into two sites; namely Plot A and Plot B of which they have different topographic contours. Plot A has a sloping topography or while Plot B is a slope or hilly area. At the time of sampling, the observed plants were in good condition, free of pests or diseases attack.

Based on the isolation and identification of endophytic fungi of the samples in plot A and plot B, a total of 55 different endophytic fungi colonies of the pepper plant (Piper nigrum Linn.) was obtained. As seen in Figure 4.A-
B and Figure 5.A-C, there were four genera of endophytic fungi in both locations, namely Aspergillus sp., Fusarium sp., Nigrospora sp., and Trichoderma sp. but the genera of Aspergillus sp. and Fusarium sp. were the most dominant. However, as seen in Table 1 that the diversity of root and leaves born endophytic fungi in Plot B was higher than Plot A.

The difference of endophytic fungal diversities in Plot A and Plot B, was determined based on calculated diversity, uniformity, and domination. This study suggests that the use of different cultivation method in each plot may affect the level of endophytic fungal diversity. It is mentioned that the presence of endophytic fungi, as well as the variations of its isolates, are affected by host species, plant parts, and location (Ghimire et al. 2011; Kivlin et al. 2013). The calculated Shannon diversity index $\left(\mathrm{H}^{\prime}\right)$, uniformity index (E), and dominance index (C) are presented in Table 2.

Table 1. The diversity of endophytic fungi in the research location

\begin{tabular}{lcc}
\hline \multirow{2}{*}{ Endophytic fungi } & \multicolumn{2}{c}{ Number of colonies } \\
\cline { 2 - 3 } & Plot A & Plot B \\
\hline Fusarium sp. & 12 & 7 \\
Nigrospora sp. & 1 & 2 \\
Trichoderma sp. & 7 & 5 \\
Aspergillus sp. & 15 & 6 \\
& & \\
S Colony & 35 & 20 \\
E Genera & 4 & 4 \\
\hline
\end{tabular}

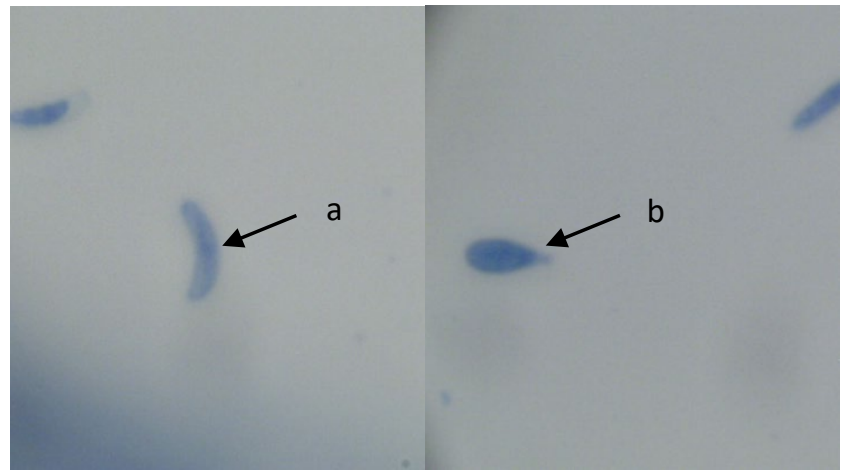

Figure 4. Microscopic features of the genus Fusarium sp isolated from pepper plants in Loa Janan, Kutai Kartanegara, Indonesia. (a) Macroconidia; (b) Microconidia

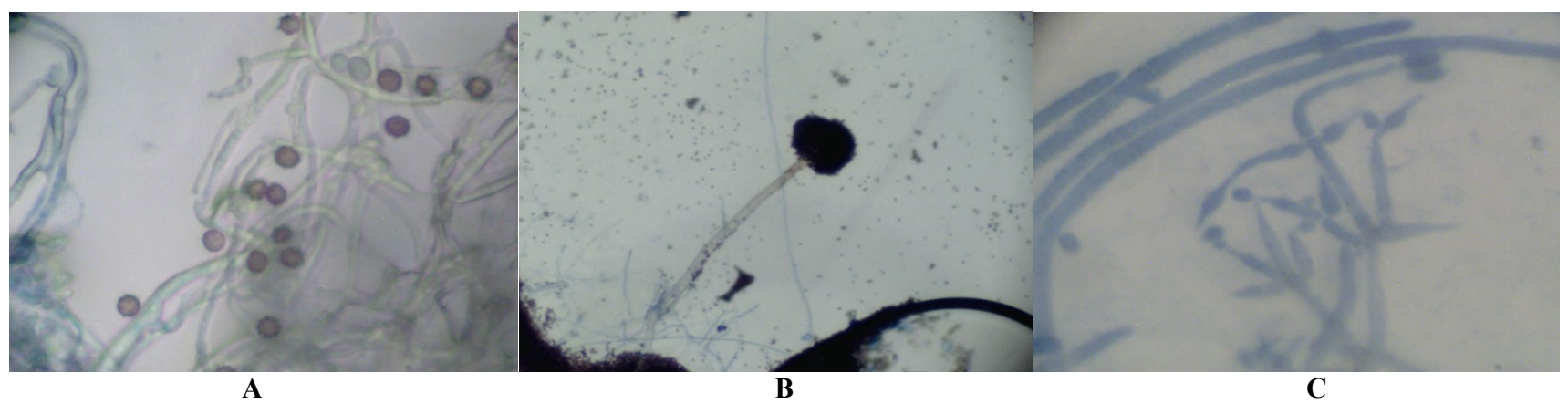

Figure 5. Microscopic features of endophytic fungi isolated from pepper plants in Loa Janan, Kutai Kartanegara, Indonesia. A. Nigrospora sp., B. Aspergillus sp., C. Trichoderma sp. 
Tabel 2. The diversity analysis of endophytic fungi in Loa Janan, Kutai Kartanegara, Indonesia

\begin{tabular}{lcccccc}
\hline \multirow{2}{*}{ Location } & \multicolumn{2}{c}{ Index value } & \multicolumn{2}{c}{$\sum_{\text {E }}$} & $\sum_{\text {Genes }}$ & $\sum$ \\
& $\mathbf{H}^{\prime}$ & $\mathbf{E}$ & $\mathbf{C}$ & \multicolumn{2}{c}{ Gecies } \\
& Colonies \\
\hline Plot A & 1.154 & 0.832 & 0.658 & 4 & 35 & 39 \\
Plot B & 1.306 & 0.942 & 0.715 & 4 & 20 & 24 \\
& & & & & & \\
Total & 2.460 & 1.774 & 1.373 & 8 & 55 & 63 \\
Average & 1.230 & 0.887 & 0.687 & 4 & 27.5 & 31.5 \\
\hline
\end{tabular}

Note: H': diversity index, E: uniformity index, C: dominance index

\section{Diversity index ( $\left.\mathrm{H}^{\prime}\right)$}

As seen in Table 2, the level of diversity of endophytic fungi was higher in Plot B as compared to that in Plot A. However, based on the criteria of the number of individuals spreading per medium species, the index value of endophytic fungi and root pepper fungi, either in Plot A (1.154), and Plot B (1.306) are considered as medium diversity. Brower and Zar (1977) stated that the index value of $<1$ is included in the criteria of low diversity with the spread of the number of individuals of each species is low. The index value of 1-3 is considered as medium diversity with the spread of the number of individuals of each species, while the index value $>3$ is included in the criteria of high diversity.

\section{Dominance Index (C)}

Table 2 shows that the level of dominance of endophytic fungi in Plot B was greater than the level of dominance of endophytic fungi in Plot A. Even so, the index values of dominance in Plots $\mathrm{A}$ and Plot $\mathrm{B}$ are categorized as medium criterion. This finding is supported by the study proposed by Hamsiah (2006) which stated that if the value of the dominant index between $0.00-0.50$ is considered low, between $0.50-0.75$ is medium, and between 0.75 to 1.00 is high.

Figure 6 indicates the result of the analysis of endophytic fungi found in the root and leaf. It can be seen that the genus of Aspergillus sp. and Fusarium sp, were dominant in both plot A and B.

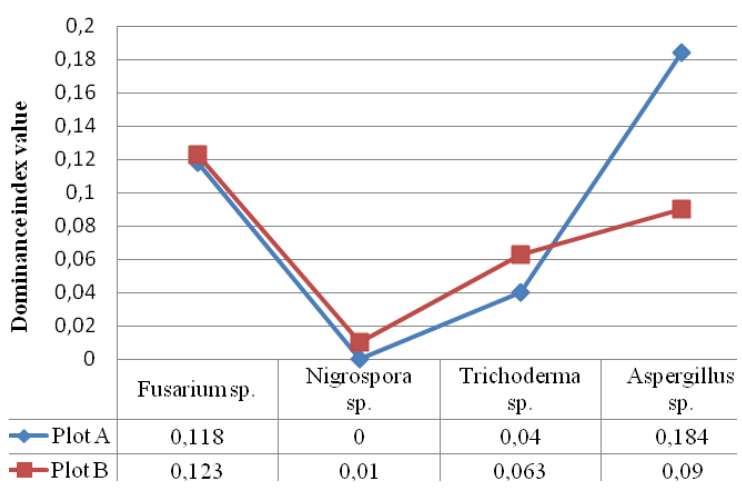

Figure 6. Dominance index

\section{Uniformity index (E)}

Based on the result shown in Table 2, the level of uniformity of endophytic fungus in Plot B was higher than that of Plot A. This finding is based on the total index uniformity of endophytic fungi in Plot A as of 0.83 , whereas the index of uniformity of endophytic fungi in Plot B was 0.94.

\section{Discussion}

This study revealed that the endophytic fungus dominated in the two different sampling sites have the same genus, i.e., Fusarium sp., Nigrospora sp., Aspergillus sp., and Trichoderma sp. This finding is in line with the study conducted by Kusumawardani et al. (2015) which located Fusarium sp. and Trichoderma sp. in the isolated endophytic fungi in pepper plant tissue. Also, several studies explained that the genus Aspergillus sp., Trichoderma sp., and Nigrospora sp. are known as endophytic fungi. Though the genera of the endophytic fungus are similar, but the number of endophytic fungi colonies at two different sampling sites was different. As many as 55 isolates of endophytic fungi were found, where, the number of isolates found in plot A was higher than that in Plot B.

However, the level of diversity of endophytic fungus in Plot B was greater than Plot A, even so, based on the spreading of some individuals of each species, both are considered as low. This is allegedly due to the influence of the cultivation methods employed by the local people which may affect the growth of fungi. In the hilly area, the diversity of endophytic fungi is higher because the humidity is better compared to sloping area. Also, this area receives more sun exposure and helps to increase the resistance of the plants to pathogens, thus the endophytic fungi can be found more as they are associated with healthy plants. Further, biotic and abiotic factors influence the abundance of endophytic fungi. Biotic factors consist of varieties and host species, while influential abiotic factors cover the weather factors, i.e., temperature, relative humidity, and groundwater content as well as the cultivation techniques (Evans and Wallenstein 2012; U' Ren et al. 2012; Craine et al., 2013). This is confirmed by Petrini et al. (1992) and David et al. (2016) that the abundance and diversity of endophytic fungi in colonizing the host is influenced by several factors such as differences in crop varieties, sampling sites, rainfall, and cultivation aspects. These factors will illustrate the high level of colonization of an endophytic fungus in the crop. In addition, the dominance of species that colonize the host will be different for each sampling (Petrini et al. 1992).

Further, among of the factors that can affect the existence of endophytic fungi is the cultivation process. This covers any adopted process to increase plant production, included the use of fertilizers and pesticides. From the observation, this study revealed that conventional farming was applied in the two sampling sites. Conventional agricultural cultivation means that the use of inorganic fertilizer and synthetic pesticides is more intensive rather than organic farming. In organic fertilizer 
farming land, manure is given in the land preparation, and then two weeks after the planting, it is continued by the biological fertilizer. On the other hand, in the conventional land, the chemical fertilizer, i.e., urea was used three times at the age of 7,21 and 35 days after planting. Though the same conventional planning was being applied, however, the sun exposure and the humidity which are different in both sites, are likely to bring different effects to the plants.

The samples of this study were the two years old pepper plants provided with fertilizers at intervals of once in every three months. The fertilizer used was compound NPK fertilizer (dose $0.5 \mathrm{~kg} /$ plant) and compost $(2 \mathrm{~kg} /$ plant $)$ given in a rotation base at three times per year.

It is commonly known that the use of pesticides brings negative effect by impeding the growth of the plants and the endophytic fungi. It is mentioned that the avoidance of pesticides has a positive effect on the number of the endophytic fungus (Compants et al. 2005; Sopialena 2014). Further, the chemical fertilizers and pesticides have chemical contents that may affect the metabolism of plants. The host plant whose metabolism is disrupted is likely to affect the amount or diversity of endophytic fungi in it.

In addition, this study also found that the cultivation method, such as plant spacing used also play an important role. The pepper plants in Batuah Village in both sampling sites were grown in plant spacing of $1.5 \mathrm{~m} \times 1.5 \mathrm{~m}$, while, the recommended distance for pepper should be $2.0 \times 2.0$ m. Ariyanto et al. (2013) said that the narrower plant spacing makes the nutrients absorbed by the plant is less than optimal, while a wider plant spacing allows the plants to have enough nutrients. Healthy and nutrient-rich plants will be able to provide the elements needed by endophytic fungi to live in plant tissues.

Based on the information collected from the Meteorology Bureau, Loa Janan is classified to have a high rainfall with the estimation of $66.9-212.7 \mathrm{~mm}$ per month. Petrini et al. (1992) stated that the high colonization of endophytic fungi is positively correlated with the altitude and environmental conditions of a place, including the rainfall. Further, the presence of endophytes depends on the plant host as long as the nutritional requirements and environmental conditions are met (Petrini 1996). Petrini et al. (1992) also found that the diversity and abundance of endophytic fungi in the Alps was very high. In addition, permanent snow cover caused high humidity which supported the development of the fungus (Sopialena and Pratiwi 2017). However, the diversity of endophytic fungi did not have a clear pattern in the distribution of each site, as the chaos and sample size was too small to identify differences in host relations in endophytic fungal colonization (Canon and Simmons 2002; Larimer et al. 2012).

Previous studies have identified some genera of endophytic fungi and their antagonistic potential ( $\mathrm{Yu}$ et al. 2010; Yan et al. 2011; Lestari et al. 2018). Kusumawardani et al. (2015) managed to isolate several types of endophytic fungi on pepper plant tissues namely Acremonium sp., Cephalosporium sp., Colletotrichum sp., Curvularia sp., Fusarium sp., Humicola sp., Scytalidium sp. and Trichoderma sp. as well as some unidentified isolates. Several endophytic fungal isolates used in the study were known to inhibit the growth of Phytophthora capsici which causes the stem rot disease in pepper plants. This is because the endophytic fungus and its host can form a mutually beneficial relationship (Narayan et al. 2013). However, in this study, there were still disease symptoms although low intensity, mainly because of the environmental factors. Other factors that allegedly affected the growth of $P$. capsici on pepper plant stems, namely the condition of vulnerable plants and the presence of inoculation when the injection, so that pathogens can easily penetrate the plant tissue and cause infection.

This study has proven the existence of endophytic fungi and its diversity living in the root and the leaf of pepper plants in Batuah village. The finding is along with the research conducted by Wahyuno et al. (2017) who also conducted endophytic fungus on pepper seeds. They concluded that not all endophytic fungi from pepper root were effective to suppress $P$. capsici attack on the seed. In addition, pepper seeds that were inoculated by endophytic fungus by immersing their rooting into the suspension of endophytic fungus culture did not have any significant effect. The endophytic fungus obtained needs to be selected to prove that the isolates obtained have a positive effect on the seeds of the pepper plant. It is found that not all endophytic fungi help plants to withstand environmental stress (Gao et al. 2010; Giauque and Hawkes 2013). The diversity of endophytic fungi species successfully isolated is also influenced by host species, plant parts, and the seasons at when the samples are collected.

This study shows that the diversity of endophytic fungi collected from the root and the leaf of pepper plants in Batuah village. The diversity in Plot B was higher compared to Plot A. There were four genera of endophytic fungi in both locations, namely Aspergillus sp., Fusarium sp., Nigrospora sp., and Trichoderma sp. but the genera of Aspergillus sp. and Fusarium sp. dominated the others.

\section{ACKNOWLEDGMENTS}

We thank our colleagues who provided assistance and useful suggestions during this research, particularly to those who helped in laboratory works and data collection.

\section{REFERENCES}

Aaron SD, Seabloom EW, May G. 2016. Plant host species and geographic distance affect the structure of aboveground fungal symbiont communities, and environmental filtering affects belowground communities in a coastal dune ecosystem. Microb Ecol 71 (4): 912-926

Ariyanto EF, Abadi AL, Djauhari S. 2013. Keanekaragaman jamur endofit pada daun tanaman padi (Oryza sativa L.) dengan sistem pengelolaan hama terpadu (PHT) dan konvensional di Desa Bayem, Kecamatan Kasembon, Kabupaten Malang. Jurnal HPT 1 (2): 37-51. [Indonesian]

Azevedo JL, Maccheroni JrW, Pereira JO, Luiz de Araújo W. 2000. Endophytic microorganisms: a review on insect control and recent advances on tropical plants. Elec J Biotechnol 3 (1): 40-65.

Barnet HL, Hunter BB. 1988. Illustrated Genera of Imperfect Fungi. 4th ed. Burgess Publishing Company, New York.

Borer ET, Kinkel LL, May G, Seabloom EW. 2013. The world within: quantifying the determinants and outcomes of a host's microbiome. Basic Appl Ecol 14: 533-539. 
Brower JE, Zar JH. 1977. Field and Laboratory Methods for General Ecology. WM. J. Brown Company Publisher, Iowa.

Canon PF, Simmons CM. 2002. Diversity and host preference of leaf endophytic fungi in the Iwokrama Forest Reserve, Guyana. Mycologia 94: 210-220.

Carrol GC. 1988. Fungal endophytes in stems and leaves. from latent pathogens to mutualistic symbiont. J Ecol 69 (1): 2-9.

Clay K. 1988. Fungal endophytes of grasses: a defensive mutualism between plants and fungi. J Ecol 69 (1): 10-16.

Compants BD, Nowak J, Clément C, Barka EA. 2005. Use of plant growth-promoting bacteria for biocontrol of plant diseases: principles, mechanisms of action, and future prospects. Appl Environ Microbio 71: 4951-4959.

Craine JM, Ocheltree TW, Nippert JB, Towne EG, Skibbe AM, Kembel SW, Fargione JE. 2013. Global diversity of drought tolerance and grassland climate-change resilience. Nature Climate Change 3: 63-67.

David AS, Seabloom EW, May G. 2016. Plant host species and geographic distance affect the structure of aboveground fungal symbiont communities, and environmental filtering affects belowground communities in a coastal dune ecosystem. Microb Ecol 71 (4): 912-26

Directorate General of Plantations GOI. 2011. Statistik perkebunan Indonesia 2010-2012: Lada. Sekretariat Direktorat Jenderal Perkebunan, Jakarta. [Indonesian]

Drigo B, Pijl AS, Duyts H, Kielak AM, Gamper HA, Houtekamer MJ, Boschker HTS. 2010. Shifting carbon flow from roots into associated microbial communities in response to elevated atmospheric $\mathrm{CO}_{2}$. Proceedings of the National Academy of Sciences, USA 107 10938-10942.

Evans SE, Wallenstein MD. 2012. Soil microbial community response to drying and rewetting stress: does historical precipitation regime matter? Biogeochemistry 109: 101-116.

Gao F, Dai C. Liu X. 2010. Mechanisms of fungal endophytes in plant protection against pathogens. Afr J Micro Biol Res 4 (13): 1346-1351.

Ghimire S, Charlton N, Bell J, Krishnamurthy Y, Craven K. 2011. Biodiversity of fungal endophyte communities inhabiting switchgrass (Panicum virgatum $\mathrm{L}$.) growing in the native tallgrass prairie of northern Oklahoma. Fungal Diversity 47: 19-27.

Giauque H, Hawkes CV. 2013. Climate affects symbiotic fungal endophyte diversity and performance. Am J Bot 100 (7): 1435-44.

Goswami R. 2015. Determination of Ecological Diversity Indices to Assess the Interrelationship between Earthworm Diversity and Different Habitats of Indian Botanic Garden, Howrah, India. Biological Forum 7 (1): 128-136

Hamsiah. 2006. Shell species potential associated with seagrass bed in Pannikiang Island, Barru Regency. Jurnal Protein 13 (2): 172-180. [Indonesian]

Hamsiah, Herawati EY, Mahmudi M, Sartimbul A. 2016. Seasonal variation of bivalve diversity in seagrass ecosystem of Labakkang coastal water, Pangkep, South Sulawesi, Indonesia. AACL Bioflux 9 (4): 775-784

Khastini RO, Ogawara T, Sato Y, Narisawa K. 2014. Control of Fusarium wilt in melon by the fungal endophyte, Cladophora sp. European J Plant Pathology 139 (2): 333-342.

Kivlin SN, Emery SM, Rudger JA. 2013. Fungal symbionts alter plan responses to global change. Am J Bot. 100 (7): 1445-1457.

Kusumawardani Y, Sulistyowati L, Cholil A. 2015. Potensi antagonis jamur endofit pada tanaman lada (Piper nigrum L.) terhadap jamu Phytophthora capsici Leionian penyebab penyakit busuk pangkal batang. Jurnal HPT 3 (1): 21-29. [Indonesian]

Labeda DP. 1990. Isolation of Actinomycetes for Biotechnology Application, Isolation of Biotechnological Organism from Nature. McGraw-Hill Publishing Company, New York.

Larimer AL, Bever JD, Clay K. 2012. Consequences of simultaneous interactions of fungal endophytes and arbuscular mycorrhizal fung with a shared host grass. Oikos 121 (12): 2090-2096

Lestari SM, Hidayat SH, Widodo. 2018. Determination of endophytic fungi as induces resistance agent of chili pepper against pepper yellow leaf curl disease. J Agric Sci 40 (2): 249-256.

Ludwig JA, Reynolds JF. 1988. Statistical Ecology: A Primer on Methods and Computing. John Wiley and Sons, Toronto

Narayan CP, Jian XD, Ji HL, Seung HY. 2013. New records of endophytic Paecilomyces inflatus and Bionectaria ochroleuca from Chili pepper Plants in Korea. Mycobiology 41 (1): 18-24.
Mandyam KG, Roe J, Jumpponen A. 2013. Arabidopsis thaliana model system reveals a continuum of responses to root endophyte colonization. Fungal Biol 117: 250-260.

Odum EP. 1971. Fundamentals of Ecology, 3rd ed. W.B. Saunders, Philadelphia.

Petrini O, Sieber TN, Toti L, Viret O. 1992. Ecology metabolite production and substrate utilization in endophytic fungi. Natural Toxins 1: $185-196$

Petrini O. 1996. Ecological and physiological aspects of host-specificity in endophytic fungi. In: Redlin CS, Carris LM (eds.). Endophyte Fungi in Grasses and Woody Plants Systematics, Ecology and Evolution. APS Press, Minnesota.

Puspita DY, Sulistyowati L, Djauhari S. 2013. Eksplorasi jamur endofit pada tanaman jeruk (Citrus sp.) fusiprotoplas dengan ketahanan berbeda terhadap Botriodiplodia theobromae Pat. Jurnal HPT 1 (3): 67-76. [Indonesian]

Rodriguez RJ, White JF, Arnold AE, Redman RS. 2009. Fungal endophytes: diversity and functional roles. New Phytol 182: 314-330.

Rubini MR, Ribeiro RTS, Pomella AWJ, Maki CS, Araujo WL, DosSantos DR, Azevedo JL. 2005. Diversity of endophytic fungal community of cacao (Theobroma cacao L.) and biological control of Crinipellis perniciosa, causal agent of Witches' Broom Disease. Intl J Biol Sci 1: 24-33.

Saunders M, Glenn AE, Kohn LM. 2010. Exploring the evolutionary ecology of fungal endophytes in agricultural systems: using functional traits to reveal mechanisms in community processes. Evol Appl 3: 525-537.

Shofiana RH, Sulistyowati L, Muhibuddin A. 2015. Eksplorasi jamur endofit dan khamir pada tanaman cengkeh (Syzygium aromaticum) serta uji potensi antagonismenya terhadap jamur akar putih (Rigidoporus microporus). Jurnal HPT 3 (1): 75-83. [Indonesian]

Sopialena. 2014. Efektivitas beberapa cara penularan virus mosaic pada tanaman cabai. Jurnal Agrifor 8 (2): 207-212. [Indonesian]

Sopialena, Pratiwi JP. 2017. Study of climatic factors on the population dynamics of Pyricularia oryzae on some varieties of paddy rize (Oryza sativa). Biodiversitas 18 (2): 701-708.

Strobel G, Daisy B. 2003. Bioprospecting for microbial endophytes and their natural products. Microbiol Mol Biol R 67: 491-502.

Suyadi, Sopialena, Nurdiana J, Suryadi A, Rosfiansyah, Waluyo S. 2017. Genus Nematoda Entomoparogen pada lahan lebak padi sawah (Oriza sativa L.) di kecamatan Muara Wis Kabupaten Kutai Kartanegara. Proceeding of Konferensi Antarbangsa Islam Borneo. Mulawarman University, Samarinda, 25 September 2017. [Indonesian]

Tejesvi MV, Ruotsalainen AL, Markkola AM, Pirttilä AM. 2010. Root endophytes along a primary succession gradient in northern Finland. Fungal Divers 41: 125-134.

Tirtana ZYG, Sulistyowati L, Cholil A. 2013. Eksplorasi jamur endofit pada tanaman kentang (solanum tuberosum L) serta potensi antagonismenya terhadap phytophthora infestans (Mont.) De Barry penyebab penyakit hawar daun secara in vitro. Jurnal HPT 1 (3): 91101. [Indonesian]

U'Ren JM, Lutzoni F, Miadlikowska J, et al. 2012. Host and geographic structure of endophytic and endolichenic fungi at a continental scale. Am J Bot 99: 898-914.

Wahyuno D, Florina D, Manohara D. 2017. Cendawan endofit akar lada untuk meningkatkan pertumbuhan dan menekan busuk pangkal batang benih lada. Balai Penelitian Tanaman Rempah dan Obat 28 (1): 57-64. [Indonesian]

Wang K, Shiwei W, Bin W, Jiguang W. 2014. Bioactive natural compounds from the mangrove endophytic fungi. Med Chem 14: 370-391

Worcher ER, Giaugue HE, Kivlin SN. 2013. Fungal symbionts alter plant drought response. Microb Ecol 65 (3): 671-678.

Wulandari D, Sulistyowati L, Muhibuddin A. 2014. Keanekaragaman jamur endofit pada tanaman tomat (Lycopersicum esculentum Mill.) dan kemampuan antagonisnya terhadap Phytophthora infestans. Jurnal HPT 2 (1): 110-118.

Yan XN, Sikora RA, Zheng JW. 2011. Potential use of cucumber (Cucumus Sativus L.) endophytic fungi as seed treatment agents against root-knot nematode Meloidogyne incognita. J Zhejiang Univ Sci B 12 (3): 219-225

Yu HS, Zhang L, Li L, Zheng CJ, Guo L, Li WC, Qin LP. 2010. Recent developments and future prospects of antimicrobial metabolites produced by endophytes. Microbiol Res 165 (6): 437-449. 